\title{
PENGARUH LEADER MEMBER EXCHANGE (LMX) DAN KOMITMEN ORGANISASI TERHADAP KINERJA KARYAWAN DENGAN MEDIASI ORGANIZATION CITIZEN BEHAVIOUR (OCB) (Studi Kasus pada Karyawan Kospin Jasa Pekalongan)
}

\author{
Aria Elshifa \\ Politeknik Pusmanu Pekalongan \\ Sekertariat PCNU Kabupaten Pekalongan Jl. Karangdowo No. 9 Kedungwuni \\ elshifapusmanu@gmail.com
}

\begin{abstract}
Achieving corporate goals depends not only on modern equipment, facilities, and complete infrastructure, but it depends on the people who carry out the work. The success of an organization is strongly influenced by the performance of its employees. The purpose of this study to determine the level of employee performance in terms of the quality of superior relationships with subordinates $(L M X)$ by taking the leadership character by employee and organizational commitment of employees through Organization Citizen Behaviour (OCB).The type of research used is the research of causality, research that aims to determine the relationship and the influence between two or more variables. The object of this research is Kospin Jasa Pekalongan.The results obtained: (1) Leader member Exchange effect on organizational citizenship Behaviour employees. (2) Organizational commitment has an effect on organizational citizenship Behaviour of Kospin Jasa Pekalongan. (3) Leader member Exchange affects the performance of employees of Kospin Jasa Pekalongan. (4) Organizational commitment affects the performance of employees of Kospin Jasa Pekalongan. (5) Organizational citizenship Behaviour affects the performance of employees of Kospin Jasa Pekalongan. (6) Leader member exchange has an indirect effect on employee performance through organizational citizenship Behaviour of Kospin Jasa Pekalongan. (7) Organizational commitment has an indirect effect on employee performance through organizational citizenship Behaviour of Kospin Jasa Pekalongan.
\end{abstract}

Keywords: Leader Member Exchange, Organizational Commitment, Employee Performance and Organization Citizen Behaviour.

\begin{abstract}
ABSTRAK
Untuk mencapai tujuan perusahaan tidak hanya bergantung pada peralatan modern, fasilitas, dan infrastruktur yang lengkap, tetapi juga dibutuhkan karyawan yang memiliki kinerja yang tinggi. Keberhasilan suatu organisasi sangat dipengaruhi oleh kinerja karyawannya. Tujuan penelitian ini untuk mengetahui kinerja karyawan ditinjau dari Leader Member Exchange (LMX) dan komitmen organisasi karyawan melalui Organization Citizen Behavior (OCB). Jenis penelitian yang digunakan adalah penelitian kausalitas, penelitian yang bertujuan untuk mengetahui hubungan dan pengaruh antara dua atau lebih variabel. Objek penelitian ini adalah Kospin Jasa Pekalongan. Hasil yang diperoleh: (1) LMX berpengaruh terhadap OCB. (2) Komitmen organisasi berpengaruh terhadap OCB Kospin Jasa Pekalongan. (3) Pertukaran Anggota Bursa mempengaruhi kinerja karyawan Kospin Jasa Pekalongan. (4) Komitmen organisasi berpengaruh terhadap kinerja karyawan Kospin Jasa Pekalongan. (5) OCB berpengaruh terhadap kinerja karyawan Kospin Jasa Pekalongan. (6) LMX memiliki pengaruh tidak langsung terhadap kinerja karyawan melalui OCB. (7) Komitmen organisasi berpengaruh tidak langsung terhadap kinerja karyawan melalui OCB.
\end{abstract}

Kata kunci: Leader Member Exchange, Komitmen Organisasi, Kinerja Karyawan, Organization Citizen Behaviour. 
1. PENDAHULUAN

Salah satu faktor yang harus diperhatikan dalam suatu perusahaan adalah sumber daya, yaitu orang atau individu yang memberikan tenaga, bakat dan kreatifitas serta usaha demi kemajuan perusahaan yang bersangkutan. Perbedaan jarak hubungan pemimpin dengan satu bawahan dengan bawahan yang lain dapat mempengaruhi pemimpin dalam menilai kinerja dan kepuasan kerja bawahan itu sendiri. Menurut Lidden dan Sparrowe Wayne, 1997 dalam (Dian dan Suharnomo, 2016) LMX berkualitas tinggi ditandai dengan saling percaya (loyalty), keinginan (contribution), rasa hormat (profesional respect) dan pengaruh timbal balik (affect) antara anggota dengan pemimpin maupun dengan tim.

Tidak hanya Leader Member Exchange (LMX) yang bagus, dalam dunia kerja, komitmen seseorang terhadap organisasi sering menjadi sesuatu yang sangat penting. Pemahaman komitmen organisasi menjadi sangatlah penting agar tercipta kondisi kerja yang kondusif sehingga perusahaan berjalan secara efektif dan efisien. Tujuannya adalah memperbaiki kesalahan-kesalahan yang terjadi. Karyawan dengan komitmen organisasi yang tinggi memiliki perbedaan sikap dibanding yang berkomitmen rendah.

$$
\text { Kinerja karyawan merupakan }
$$
permasalahan yang akan selalu dihadapi oleh pihak manajemen sebuah organisasi, oleh karena itu manajemen perlu mengetahui faktor yang dapat mempengaruhi kinerja karyawan.

Persepsi karyawan yang baik terhadap dukungan organisasional kepada kualitas kehidupan kerja mereka akan menimbulkan rasa hutang budi dalam diri mereka pada organisasi sehingga mereka akan merasa memilliki kewajiban untuk membayarnya. Karyawan yang merasa bahwa mereka didukung oleh organisasi akan memberikan timbal balik (feed back) dan menurunkan ketidakseimbangan dalam hubungan dengan terlibat dalam perilaku citizenship. Sistem kepemimpinan Leader Member Exchange (LMX) dapat menghasilkan feedback antar inidividu tanpa terpengaruh batas atau strata sosial.

Kospin Jasa Pekalongan merupakan koperasi simpan pinjam terbesar yang ada di Pekalongan dimana dalam kegiatan operasinya hampir sama dengan lembaga keuangan pada umumnya. Koperasi ini sudah ada sejak lama yaitu sekitar 45 tahun.Dalam kegiatan operasionalnya koperasi pada beberapa masalah mengenai karyawan yang beragam diantaranya mengenai perilaku mereka di tempat kerja, karyawan yang kurang dapat diajak kerjasama, rasa kepedulian karyawan yang rendah, mereka yang seringkali bekerja secara individual, ada juga yang terlalu tertutup dan susah berinteraksi dengan karyawan lain maupun dengan pimpinannya. Hal tersebut memberikan dampak berupa rendahnya hubungan yang terjadi diantara atasan dengan bawahan maupun antara karyawan dengan karyawan lain, dan bahkan berakibat pada rendahnya komitmen dari karyawan untuk berupaya memajukan perusahaan .Permasalahan yang terjadi tersebut dikhwatirkan menimbulkan penurunan kinerja dan menimbulkan perselisihan antara atasan dan bawahan.

Berdasarkan uraian diatas, dapat disimpulkan bahwa perbedaan jarak hubungan pemimpin dengan satu bawahan yang lain dapat mempengaruhi hasil kinerja. Semakin tinggi tingkat hubungan maka semakin baik kinerja karyawan baik kinerja pokok maupun kinerja tambahannya. Kedekatan hubungan atasan dan bawahan dalam melaksanakan pekerjaan merupakan salah satu bentuk kontribusi komitmen organisasi karyawan terhadap perusahaan 
dalam melaksanakan pekerjaan melebihi tugas wajibnya.

Tujuan dari penelitian ini adalah:

1. Mengetahui dan menganalisis pengaruh langsung Leader Member Exchange (LMX) terhadap Organization Citizen Behaviour (OCB).

2. Mengetahui dan menganalisis pengaruh langsung komitmen organisasiterhadap Organization Citizen Behaviour (OCB).

3. Mengetahui dan menganalisis pengaruh langsung Leader Member Exchange (LMX)terhadap kinerja.

4. Mengetahui dan menganalisis pengaruh langsung komitmen organisasi terhadap kinerja.

5. Mengetahui dan menganalisis pengaruh langsung Organization Citizen Behaviour (OCB) terhadap kinerja karyawan.

6. Mengetahui dan menganalisis pengaruh tidak langsung Leader Member Exchange (LMX) terhadap kinerja melalui Organization Citizen Behaviour (OCB).

7. Mengetahui dan menganalisis pengaruh tidak langsung komitmen organisasi terhadap kinerja melalui Organization Citizen Behaviour (OCB).

\section{TINJAUAN PUSTAKA}

\subsection{Landasan Teori}

Leader member exchange (LMX) menurut Morrow (2005:682) adalah peningkatan kualitas hubungan antara supervisi dengan karyawan akan mampu meningkatkan kerja keduanya. Namun realitasnya, hubungan antara karyawan dan supervisi dapat dikelompokkan pada dua hubungan yaitu hubungan yang baik dan hubungan yang buruk. Hubungan yang baik akan menciptakan kepercayaan karyawan, sikap positif, dan loyalitas, namun hubungan yang buruk berpengaruh sebaliknya.
Menurut Truckenbrodt (2002:233) bahwa leader member exchange difokuskan pada penilaian terhadap hubungan dan interaksi antara supervisor (atasan) dan bawahan. Tingkat kedekatan dari hubungan antara pimpinan dan bawahan ini yang menunjukkan adanya indikasi dari leader member exchange di perusahaan.

Menurut Dessler (2000) dalam Djati dan Khusaini (2003:32) komitmen organisasi dapat didefinisikan sebagai kekuatan relatif identifikasi individu terhadap organisasinya, yang dapat dilihat paling tidak dengan 3 faktor, antara lain (1) kepercayaan dan penerimaan yang kuat atas tujuan dan nilainilai organisasi (2) kemauan untuk mengusahakan kepentingan organisasi (3) keinginan yang kuat untuk mempertahankan jadi anggota organisasi.

\section{Definisi Organizational Citizenship} Behaviour (OCB) berpusat kepada perilaku tiap individu yang melaksanakan tugasnya yang melebihi dari deskripsi kerjanya. Organ dalam Djati (2009:22) memberikan pengertian OCB sebagai bentuk perilaku yang merupakan pilihan dan inisiatif individual untuk meningkatkan efiseinsi kinerja organisasi dengan membantu tujuan dari produktifitas individu pegawai. OCB merupakan kontribusi individu yang melebihi tuntutan peran di tempat kerja dan di-reward oleh perolehan kinerja tugas. Menurut Mangkunegara (2011:97), istilah kinerja berasal dari kata "job performance" atau "actual performance" yaitu unjuk kerja atau prestasi sesungguhnya yang dicapai oleh seseorang dalam melaksanakan tugas sesuai dengan tanggung jawab yang diberikan kepadanya. Baron dan Greenberg (1990) dalam Armanu (2005:69) mengemukakan bahwa kinerja pada individu juga disebut 
dengan job performance, work outcomes, task performance.

Robbins (2001) dalam Asri (2010:98), kinerja dianggap sebagai banyaknya upaya yang dikeluarkan individupada pekerjaannya. Sementara Bernandin dan Russell dalam Asri (2010:98), performansi adalah catatan yang dihasilkan dari fungsi suatu pekerjaan tertentu atau kegiatan selama periode waktu tertentu. Secara sederhana, Mathis dan Jackson (2006:378) mendefinisikan kinerja sebagai apa yang dilakukan atau tidak dilakukan oleh karyawan.

\subsection{Kerangka Pemikiran Teoritis dan Perumusan Hipotesis}

Kualitas interaksi atasan-bawahan akan memberikan dampak meningkatkan kepuasan kerja, produktifitas, dan kinerja karyawan. Perilaku interaksi sosial anggota organisasi yang lancar akan mengurangi terjadinya perselisihan, dan meningkatkan efisiensi. Hubungan dengan pemimpin menjadi faktor yang mempengaruhi kinerja karyawan. Apabila karyawan mempunyai hubungan buruk dengan pemimpinnya, karyawan tersebut cenderung untuk bekerja tidak secara maksimal dan dapat mempengaruhi perusahaan. Selain hubungan dengan pemimpin, hubungan antar sesama rekan kerja juga penting, karena pada dasarnya kinerja merupakan kemampuan seorang atau kelompok untuk memenuhi tanggung jawab.

Faktor penentu utama dari terbentuknya komitmen organisasi adalah kepemimpinan. Pemimpin merupakan faktor utama terbentuknya komitmen organisasi, karena merupakan pembentuk lingkungan kerja dan persepsi karyawan mengenai pekerjaan dan perusahaan tempat bekerja. Semakin positif persepsi karyawan terhadap peran pemimpin maka akan semakin tinggi pula komitmen organisasi yang dimiliki sehingga dapat berimplementasi terhadap meningkatnya kinerja karyawan. Komitmen dan perilaku karyawan yangmenguntungkan bagi perusahaan didukung oleh seberapa kuat keterikatan yang dimiliki oleh karyawan terhadap team atau terlebih dengan pemimpin.

Saat ini, perusahaan membutuhkan karyawan yang berkualitas tinggi dan memiliki komitmen yang tinggi untuk dapat bertahan dalam bisnis. Komitmen yang tinggi akan mendorong karyawan untuk menjadi lebih kreatif dan inovatif. Komitmen karyawan yang tinggi akan memberikan pengaruh yang signifikan terhadap kinerja organisasi. Komitmen yang tinggi terhadap organisasi cenderung akan memberikan pemikiran dan tenaganya pada organisasi.

Kerangka pemikiran dapat digambarkan sebagai berikut:

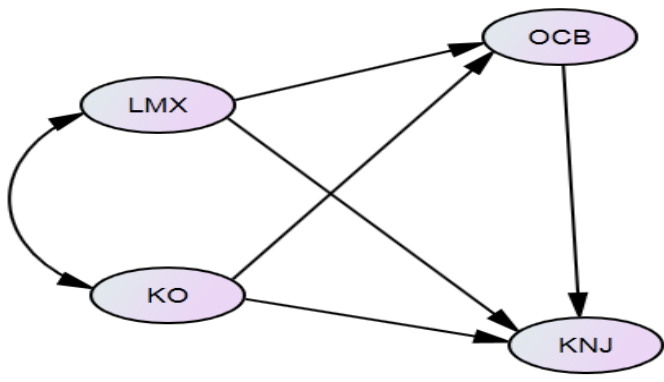

Gambar 1. Kerangka Pemikiran

Hipotesis dapat dirumuskan sebagai berikut:

Leader Member Exchange (LMX) menurut Morrow (2005:682) adalah peningkatan kualitas hubungan antara supervisi dengan karyawan akan mampu meningkatkan kerja keduanya. Namun realitasnya, hubungan antara karyawan dan supervisi dapat dikelompokkan pada dua hubungan yaitu hubungan yang baik dan hubungan yang buruk. Hubungan yang baik akan menciptakan kepercayaan karyawan, sikap positif, dan loyalitas, namun hubungan yang buruk berpengaruh sebaliknya. 
Leader Member Exchange mempunyai pengaruh yang significan pada OCB karyawan sebagai LMX yang tinggi memotivasi karyawan untuk memperlihatkan perilaku extra-role tanpa penghargaan formal dari organisasi tersebut (Wayne, Shore, Bommer \& Tetrick dalam Asgari, et, al., 2008, p.142). Sedangkan penelitian Oktavio, Adrie (2013) menyimpulkan LMX tidak berpengaruh secara signifikan terhadap OCB. Berdasarkan uraian di atas, maka hipotesis pertama dalam penelitian ini adalah:

\section{H1 : Leader Member Exchange (LMX)berpengaruh langsung terhadap Organization Citizen Behaviour (OCB)}

Komitmen organisasi merupakan identifikasi dan keterlibatan seseorang yang relatif kuat terhadap organisasinya. Komitmen organisasi adalah keinginan para anggota organisasi tetap mempertahankan keanggotaan dalam organisasi dan bersedia melakukan usaha yang tinggi bagi pencapaian tujuan organisasi.

Penelitian yang dilakukan Hidayat dan Kusumawati (2014) menyatakan bahwa komitmen organisasi mempunyai pengaruh yang signifikan dan positif terhadap Organizational Citizen Behaviour (OCB). Dari uraian diatas, maka dugaan sementara yaitu diduga terdapat pengaruh langsung komitmen organisasional terhadap Organization Citizen Behaviour (OCB). Berdasarkan uraian di atas, maka hipotesis dalam penelitian ini adalah:

\section{H2 : Komitmen organisasi berpengaruh langsung terhadap Organization Citizen Behaviour (OCB)}

Salah satu yang harus diperhatikan oleh para pemimpin adalah kualitas hubungan antara pemimpin dan karyawan. Teori yang mengatur hubungan antara pemimpin dan karyawan ini disebut Leader Member Exchange atau yang lebih dikenal dengan istilah LMX. Menurut Organ (1998) sebagaimana dikutip oleh Bhal (2006:107) leader member exchange sebagai perilaku karyawan terhadap perusahaan mempunyai peran penting terhadap keberhasilan sebuah organisasi.

Keterkaitan antara Leader Member Exchange dengan kinerja ini telah dibuktikan oleh beberapa ahli seperti Wang (2001) yang berpendapat bahwa Leader Member Exchange terkait secara positif dengan kinerja karyawan. Arsintadiani dan Harsono (2002) juga telah membuktikan bahwa Leader Member Exchange berpengaruh secara positif terhadap kinerja karyawan. Berdasarkan uraian di atas, maka hipotesis dalam penelitian ini adalah:

\section{$\mathrm{H3}$ : Leader Member Exchange (LMX) berpengaruh langsung terhadap kinerja}

Komitmen organisasi adalah keinginan kuat untuk tetap sebagai anggota organisasi tertentu, keinginan untuk berusaha keras sesuai dengan keinginan organisasi, serta keyakinan tertentu dan penerimaan nilai dan tujuan organisasi. Sikap yang merefleksikan loyalitas karyawan pada organisasi dan proses berkelanjutan dimana anggota organisasi mengekspresikan perhatiannya terhadap organisasi dan keberhasilan serta kemajuan yang berkelanjutan (Luthan, 2006).

Pengaruh komitmen organisasi terhadap kinerja karyawan seperti menurut penelitian Hong (2012) yaitu Organizational Commitment will positively and significantly affect job performance. Penelitian Ghorbanpour, Dehnavi, Heyrani (2014) yaitu komitmen organisasi memiliki pengaruh positif yang signifikan pada kinerja 
karyawan. Sedangkan penelitian Arizona, Riniwati Harahap (2013) mengatakan secara parsial komitmen organisasional tidak mempunyai pengaruh yang signifikan terhadap kinerja pegawai. Berdasarkan uraian di atas, maka hipotesis dalam penelitian ini adalah:

\section{H4 : Komitmen \\ Organisasiberpengaruh langsung terhadap kinerja}

\section{Organizational Citizenship Behaviour} (OCB) dianggap sebagai suatu perilaku di tempat kerja yang sesuai dengan penilaian pribadi yang melebihi persyaratan kerja dasar seseorang. OCB juga dapat dijelaskan sebagai perilaku yang melebihi permintaan tugas.

Hubungan antara OCB dengan kinerja dalam jurnal yang dikemukakan oleh Waltz dan Niehoff (2004) menunjukan adanya tingkat efektiftas dalam organisasi dengan adanya karyawan dengan OCB. Hal ini mendukung perkembangan kinerja karyawan seperti yang diungkapkan oleh Nufus (2011) dalam penelitiannya yang membahas mengenai OCB terhadap kinerja. Dalam penelitiannya mengungkapkan pengaruh signifikan antara aspek OCB dengan kinerja karyawan. Berdasarkan uraian di atas, maka hipotesis dalam penelitian ini adalah:

\section{H5 : Komitmen \\ Organisasiberpengaruh langsung terhadap kinerja}

Karyawan yang memiliki kualitas interaksi yang tinggi dengan atasannya dapat mengerjakan pekerjaan selain yang biasa mereka lakukan, sedangkan karyawan yang memiliki kualitas interaksi yang rendah dengan atasannya cenderung menunjukkan pekerjaan yang rutin saja dari sebuah kelompok kerja OCB dapat didefinisikan sebagai perilaku yang dikerjakan lebih sekedar perilaku dasar sesuai dengan kontrak yang disepakati oleh seorang karyawan. Berdasarkan uraian di atas, maka hipotesis pertama dalam penelitian ini adalah:

\section{H6 : Leader Member Exchange (LMX) berpengaruh terhadap kinerja melalui Organization Citizen Behaviour (OCB)}

Komitmen organisasi merupakan ikatan psikis individu terhadap organisasi yang mencakup keterlibatan kerja, kesetiaan, dan kepercayaan terhadap nilai organisasi. Semakin tinggi komitmen organisasi yang dimiliki dapat berimplementasi terhadap meningkatnya kinerja karyawan. Komitmen dan perilaku karyawan yang menguntungkan bagi perusahaan didukung oleh seberapa kuat keterikatan yang dimiliki oleh karyawan terhadap team atau terlebih dengan pemimpin. Pemimpin perlu mengetahui sebarapa jauh sikap dan pertukaran yang ia miliki dengan bawahan dalam mempengaruhi persepsi bawahannya mengenai LMX dan dalam memprediksi munculnya komitmen organisasi. Berdasarkan uraian di atas, maka hipotesis pertama dalam penelitian ini adalah:

\begin{tabular}{rlr} 
H7 : & Komitmen & \multicolumn{2}{c}{ Organisasi } \\
& berpengaruh terhadap kinerja \\
& melalui Organization Citizen \\
& Behaviour $($ OCB $)$
\end{tabular}

\section{METODE PENELITIAN}

\subsection{Populasi dan Sampel}

Populasi dalam penelitian ini adalah seluruh karyawan Kospin Jasa Pekalongan sebanyak 1.486 orang. Dari jumlah populasi tersebut ditentukan jumlah sampel dengan menggunakan perhitungan slovin diperoleh jumlah sampel sebanyak 120 orang dengan menggunakan teknik sampling Stratified Random Sampling yakni penyebaran wakil sampel dari setiap kelompok/strata ditetapkan 
secara proporsional sehingga strata atau kelompok populasi terwakili oleh sampel yang proporsional.

\subsection{Definisi dan Operasional Variabel a. Variabel Independen atau Variabel eksogen.}

Variabel independen merupakan variabel yang mempengaruhi atau menjadi sebab timbulnya atau berubahnya variabel dependen (variabel terikat). Dalam penelitian ini variabel independennya adalah Leader Member Exchange (LMX) dan komitmen organisasi.

\section{Leader Member Exchange (LMX)}

Truckenbrodt (2002:233) menyatakan bahwa leader member exchange difokuskan pada penilaian terhadap hubungan dan interaksi antara supervisor (atasan) dan bawahan. Tingkat kedekatan dari hubungan antara pimpinan dan bawahan ini yang menunjukkan adanya indikasi dari leader member exchange di perusahaan.

Menurut pendapat Trucken Brodt (2002:234) mengatakan indikator variabel leader member exchange antara lain:

a. Tingkat perlakuan-perlakuan khusus yang diberikan pimpinan kepada karyawan.

b. Tingkat perhatian yang memadai dari pimpinan terhadap karyawan.

c. Tingkat kepercayaan pimpinan terhadap karyawan dan sebaliknya.

d. Tingkat kesediaan menerima tambahan tanggungjawab dari perusahaan.

e. Tingkat kesediaan karyawan untuk menerima tugas yang tidak terstruktur.

f. Tingkat kesediaan karyawan untuk secara sukarela bekerja tambahan diperusahaan.

2. Komitmen Organisasi.

Komitmen organisasional merupakan sikap yang merefleksikan loyalitas karyawan pada organisasi dan proses berkelanjutan dimana anggota organisasi mengekspresikan perhatiannya terhadap organisasi dan keberhasilan serta kemajuan berkelanjutan.

Menurut Mowdey, et al. 1982 (dalam Wulandari, 2015) untuk mengukur komitmen organisasi, digunakan indikator yaitu :

a. Loyalitas terhadap organisasi

b. Bangga menjadi bagian dari organisasi

c. Keinginan kuat untuk bertahan dalam organisasi

d. Persamaan nilai-nilai organisasi, yaitu penerimaan nilai-nilai organisasi dimana masalah organisasi menjadi bagian dari masalah individu.

e. Organisasi memberikan kesempatan dalam pencapaian prestasi kerja.

f. Keinginan berusaha keras demi kesuksesan organisasi, tampak melalui kesediaan bekerja melebihi apa yang diharapkan organisasi dapat maju.

g. Keterikatan secara emosional dengan organisasi.

3. Variabel Intervening.

Dalam penelitian ini yang merupakan variabel intervening adalah Organization Citizen Behaviour (OCB). Menurut (Organ et al, 2006) Indikator dalam OCB antara lain :

1. Kerjasama tim (altruism).

2. Disiplin dalam bekerja (conscientiousness).

3. Tidak mengeluh dalam bekerja (sportmanship).

4. Menjaga citra perusahaan (courtesy).

5. Profesional dalam menggunakan aset (civic vertue).

\section{b. Variabel Dependen atau Variabel Endogen}

Dalam penelitian ini yang merupakan variabel terikatnya adalah kinerja karyawan. Menurut Soedjono (2005) kinerja sebagai hasil kerja secara kualitas dan kuantitas yang 
dapat dicapai oleh seorang pegawai dalam melaksanakan tugas sesuai dengan tugas dan tanggungjawab yang diberikan kepadanya. Adapun indikator kinerja menurut Bernadin dan Russel (2003) adalah: Kualitas, Kuantitas, Ketepatan waktu, Kemampuan dan Tanggungjawab terhadap pekerjaan.

\subsection{Analisis Data}

Penelitian ini menggunakan teknik multivariat Structural Equation Modeling (SEM). Pemilihan teknik analisis SEM didasarkan pertimbangan bahwa SEM memiliki kemampuan untuk menggabungkan measurement model dan structural model secara simultan dan efisien bila dibandingkan dengan teknik multivariat lainnya. Measurement model digunakan untuk menguji dimensi dari sebuah konstruk yang merupakan latent variable. Structural Equation memperlihatkan hubungan kausalitas antar berbagai kontruk dalam model. Software yang dipergunakan untuk mengolah data adalah AMOS.

\section{HASIL DAN PEMBAHASAN}

\subsection{Analisis Structural Equation Model} (SEM)

Analisis Structural Equation Modeling digunakan untuk mengetahui hubungan struktural antara variabel yang diteliti. Hubungan struktural antar variabel diuji kesesuaiannya dengan Goodness Of-fit index. Hasil analisis Structural Equation Modeling dalam penelitian ini dapat dilihat pada gambar 2 berikut.

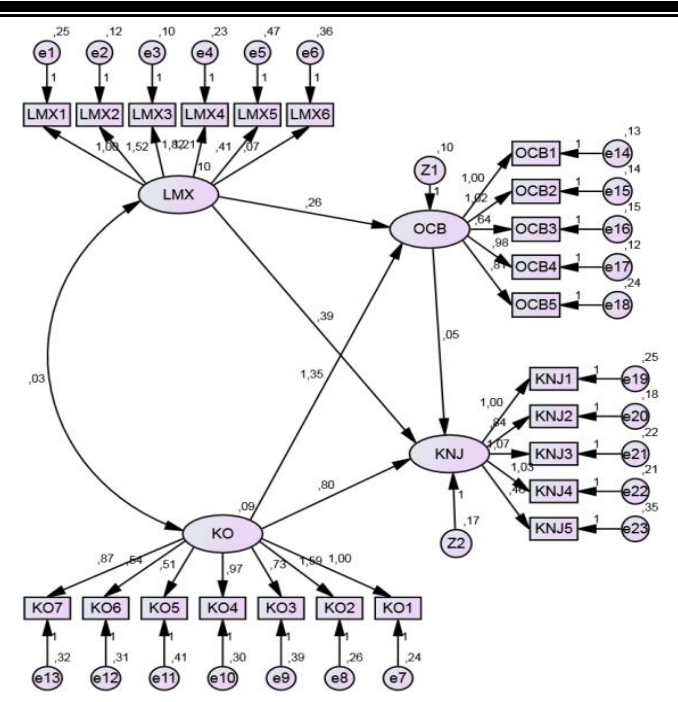

Gambar 2. Structural Equation Model

Dari gambar 2 nilai Goodness of-Fit SEM dapat dilihat pada tabel 1

Tabel 1. Uji Model Goodness of-Fit SEM

\begin{tabular}{|c|c|c|c|}
\hline $\begin{array}{c}\text { Goodnes } \\
\text { of Index }\end{array}$ & $\begin{array}{c}\text { Cut-off } \\
\text { Value }\end{array}$ & $\begin{array}{c}\text { Hasil } \\
\text { Model }\end{array}$ & Ket \\
\hline Chi-square & Kecil & 260,812 & Baik \\
\hline Probability & $\geq 0,05$ & 0,109 & Baik \\
\hline RMSEA & $\leq 0,08$ & 0,026 & Baik \\
\hline TLI & $\geq 0,90$ & 0,986 & Baik \\
\hline GFI & $\geq 0,90$ & 0,904 & Baik \\
\hline AGFI & $\geq 0,90$ & 0,964 & Baik \\
\hline CFI & $\geq 0,90$ & 0,982 & Baik \\
\hline CMIN/DF & $<2$ & 1,472 & Baik \\
\hline
\end{tabular}

Sumber: Data primer yang diolah (2018)

Berdasarkan tabel di atas diperoleh nilai chi square 260,812 dengan probabilitas 0,109 $>0,05$, nilai RMSEA sebesar $0,026<0,08$, nilai TLI sebesar $0,986>0,90$, nilai GFI sebesar 0,904>0,90, nilai AGFI sebesar $0,964>0,90$, nilai CFI sebesar 0,982>0,90 dan nilai CMIN/DF sebesar 1,472 menunjukkan bahwa uji kesesuaian model ini menghasilkan sebuah penerimaan yang baik. Oleh karena itu, dapat disimpulkan bahwa struktur analisis modeling dalam penelitian ini dapat dilakukan. 
Pengaruh Leader Member Exchange

(LMX) dan Komitmen Organisasi

(KO)terhadap Organizational Citizenship

Behaviour(OCB). Leader Member Exchange

(LMX), Komitmen Organisasi (KO) dan

Organizational Citizenship Behaviour(OCB)

terhadap Kinerja (KNJ).

Tabel 2. Regression Weight Regression Weights: (Group number 1 - Default model)

\begin{tabular}{|c|c|c|c|c|c|c|}
\hline & & & Estimate & S.E. & C.R. & $\mathrm{P}$ \\
\hline OCB & $<---$ & LMX & 1,258 & ,369 & 3,409 & ,016 \\
\hline OCB & $<---$ & $\mathrm{KO}$ & 1,351 & ,337 & 4,008 & $* * *$ \\
\hline KNJ & $<---$ & LMX & ,391 & , 182 & 2,149 & ,032 \\
\hline $\mathrm{KNJ}$ & $<---$ & $\mathrm{KO}$ & 1,296 & , 460 & 2,817 & ,022 \\
\hline KNJ & $<---$ & OCB & ,755 & ,222 & 3,401 & 017 \\
\hline LMX2 & $<---$ & LMX & 1,518 & ,267 & 5,680 & $* * *$ \\
\hline LMX3 & $<---$ & LMX & 1,817 & ,327 & 5,560 & $* * *$ \\
\hline LMX4 & $<---$ & LMX & 1,212 & ,230 & 5,276 & $* * *$ \\
\hline LMX5 & $<---$ & LMX & 608 & ,225 & 2,702 &, 007 \\
\hline KO3 & $<---$ & $\mathrm{KO}$ & ,730 & ,260 & 2,814 &, 005 \\
\hline $\mathrm{KO} 4$ & $<---$ & $\mathrm{KO}$ & ,973 & ,260 & 3,740 & $* * *$ \\
\hline KO5 & $<---$ & $\mathrm{KO}$ & ,509 & ,247 & 2,061 & ,039 \\
\hline OCB1 & $<---$ & OCB & 1,000 & & & \\
\hline OCB2 & $<---$ & OCB & 1,021 & ,098 & 10,418 & $* * *$ \\
\hline OCB3 & $<---$ & OCB & ,639 & ,080 & 7,948 & $* * *$ \\
\hline OCB4 & $<---$ & OCB & ,980 & ,093 & 10,497 & $* * *$ \\
\hline OCB5 & $<---$ & OCB & ,815 & , 104 & 7,841 & $* * *$ \\
\hline KNJ1 & $<---$ & KNJ & 1,000 & & & \\
\hline KNJ2 & $<---$ & KNJ & ,842 & , 121 & 6,974 & $* * *$ \\
\hline KNJ3 & $<---$ & KNJ & 1,075 &, 150 & 7,156 & $* * *$ \\
\hline KNJ4 & $<---$ & KNJ & 1,027 & , 136 & 7,556 & $* * *$ \\
\hline KNJ5 & $<---$ & $\mathrm{KNJ}$ & ,461 & ,123 & 3,755 & $* * *$ \\
\hline LMX6 & $<---$ & LMX & , 466 & , 185 & 2,519 & ,011 \\
\hline KO1 & $<---$ & $\mathrm{KO}$ & 1,000 & & & \\
\hline KO7 & $<---$ & $\mathrm{KO}$ & ,870 & ,228 & 3,815 & $* * *$ \\
\hline KO6 & $<---$ & $\mathrm{KO}$ & ,537 & ,220 & 2,442 & ,015 \\
\hline $\mathrm{KO} 2$ & $<---$ & $\mathrm{KO}$ & 1,592 & ,370 & 4,297 & $* * *$ \\
\hline LMX1 & $<---$ & LMX & 1,000 & & & \\
\hline
\end{tabular}

Sumber: Data primer yang diolah (2018)

Pada output di atas dapat dibuat persamaan sebagai berikut:

$\mathrm{OCB}=1,258 \mathrm{LMX}+1,351 \mathrm{KO}$

\section{$\mathrm{KNJ}=0,391 \mathrm{LMX}+1,296 \mathrm{KO}+$ $0,775 \mathrm{OCB}$}

Dari persamaan ini diketahui bahwa koefisien Leader Member Exchange (LMX) dan Komitmen Organisasi (KO) memiliki nilai positif atau meningkatkan Organizational Citizenship Behaviour(OCB) dan Kinerja (KNJ).

\subsection{Pengujian Hipotesis}

Hasil pengujian hipotesis pengaruh Leader Member Exchange (LMX) dan Komitmen Organisasi (KO)terhadap Organizational Citizenship Behaviour(OCB). Leader Member Exchange (LMX), Komitmen Organisasi (KO) dan Organizational Citizenship Behaviour(OCB) terhadap Kinerja (KNJ). Hasil output hipotesis sebagai berikut:

a. Pengaruh LMX ke OCB diperoleh nilai 1,258 dengan nilai $P$-value sebesar 0,016 lebih kecil dari 0,05, sehingga Leader Member Exchange berpengaruh signifikan terhadap Organizational Citizenship Behaviourpada karyawan Kospin Jasa Pekalongan.

b. Pengaruh $\mathrm{KO}$ ke OCB diperoleh nilai 1,351 dengan nilai $P$-value sebesar 0,000 lebih kecil dari 0,05, sehingga Komitmen Organisasi berpengaruh signifikan terhadap Organizational Citizenship Behaviour pada karyawan Kospin Jasa Pekalongan.

c. Pengaruh LMX ke KNJ diperoleh nilai 0,391 dengan nilai $P$-value sebesar 0,032 lebih kecil dari 0,05, sehingga Leader Member Exchange berpengaruh signifikan terhadap Kinerja pada karyawan Kospin Jasa Pekalongan.

d. Pengaruh $\mathrm{KO}$ ke KNJ diperoleh nilai 1,296 dengan nilai $P$-value sebesar 0,022 lebih kecil dari 0,05 , sehingga Komitmen Organisasi berpengaruh 
signifikan terhadap Kinerja pada karyawan Kospin Jasa Pekalongan.

e. Pengaruh OCB ke KNJ diperoleh nilai 0,775 dengan nilai $P$-value sebesar 0,017 lebih kecil dari 0,05, sehingga Komitmen Organisasi berpengaruh signifikan terhadap Organizational Citizenship Behaviour padakaryawan Kospin Jasa Pekalongan

f. Pengaruh LMX terhadap KNJ dengan diintervening $\mathrm{OCB}$

Pengaruh langsung LMX ke KNJ sebesar 0,391.

Pengaruh tidak langsung LMX ke OCB ke KNJ sebesar $1,258 \times 0,775=0,974$ Total Pengaruh LMX terhadap KNJ sebesar $0,391+0,974=1,365$

Dari perhitungan di atas menunjukkan hasil uji intervening sebesar0,974 karena pengaruh langsung lebih kecil dari pengaruh tidak langsung, maka Organizational Citizenship Behaviour (OCB) merupakan variabel intervening yang memperkuat pengaruh Leader Member Exchange (LMX) terhadap Kinerja (KNJ) pada Kospin Jasa Pekalongan.

g. Pengaruh KO terhadap KNJ dengan diintervening OCB

Pengaruh langsung $\mathrm{KO}$ ke KNJ sebesar $1,296$.

Pengaruh tidak langsung $\mathrm{KO}$ ke OCB ke KNJ sebesar 1,351 x 0,775 $=1,047$

Total Pengaruh KO terhadap KNJ sebesar 1,296 + 1,047 = 2,343.

Dari perhitungan di atas menunjukkan hasil uji intervening sebesar 1,047 karena pengaruh langsung lebih besar dari pengaruh tidak langsung, maka Organizational Citizenship Behaviour (OCB) merupakan variabel intervening yang memperlemah pengaruh Komitmen Organisasi (KO) terhadap Kinerja (KNJ) pada Kospin Jasa Pekalongan.

\subsection{Pembahasan}

a. Pengaruh Leader Member Exchange (LMX) Terhadap Organizational Citizenship Behaviour (OCB)

Hasil penelitian diperoleh nilai 1,258 dengan nilai $P$-value (signifikan) sebesar 0,016 lebih kecil dari 0,05, sehingga Leader Member Exchange (LMX) berpengaruh signifikan terhadap Organizational Citizenship Behaviour (OCB) pada karyawan Kospin Jasa Pekalongan.Hal tersebut menunjukkan secara statistik dapat ditunjukkan bahwa dalampenelitian ini Leader Member Exchange (LMX) memiliki pengaruh positif dengan Organizational Citizenship Behaviour (OCB). Sehingga semakin tinggi Leader Member Exchange (LMX) seorang pemimpin maka akan dapat meningkatkan Organizational Citizenship Behaviour (OCB).

Teori Leader Member Exchange (LMX) telah menyajikan suatu kerangka bermanfaat menguji hubungan antara supervisor dan para bawahan dan telah menjadi fokus banyak penelitian (Gerstner dan Day; Graen dan UhlBien dalam Harris et al., 2007). Teori LMX bervariasi dari teori kepemimpinan lainnya, bahwa pemimpin mengembangkan hubungan yang berbeda dengan para bawahannya (Harris et al., 2007).

Hasil penelitian ini konsisten dengan hasil penelitian yang dilakukan oleh Wayne, Shore, Bommer \& Tetrick dalam Asgari, et, al. (2002), yang menyatakan bahwa Leader Member Exchange mempunyai pengaruh yang significan pada OCB karyawan sebagai LMX yang tinggi memotivasi karyawan untuk memperlihatkan perilaku extra-role tanpa penghargaan formal dari organisasi tersebut. Sedangkan hasil penelitian ini berbeda dengan penelitian yang dilakukan 
Andre Oktavio (2013) menyimpulkan

LMX tidak berpengaruh secara signifikan terhadap OCB.

\section{b. Pengaruh Komitmen Organisasional Terhadap Organizational Citizenship Behaviour}

Hasil penelitian diperoleh nilai 1,351 dengan nilai $P$-value (signifikan) sebesar 0,000 lebih kecil dari 0,05 , sehingga Komitmen Organisasi berpengaruh signifikan terhadap Organizational Citizenship Behaviour pada karyawan Kospin Jasa Pekalongan. Pada saat karyawan telah memiliki komitmen yang tinggi terhadap perusahaan, maka karyawan tersebut dengan sepenuh hati memiliki kepuasan dalam bekerja, dan rela melakukan tindakan yang bertujuan memajukan perusahaan. $\mathrm{Hal}$ tersebut menunjukkan perilaku karyawan Organizational Citizenship Behaviour menjadi lebih baik.

Komitmen organisasi merupakan identifikasi dan keterlibatan seseorang yang relatif kuat terhadap organisasinya. Komitmen organisasi adalah keinginan para anggota organisasi untuk tetap mempertahankan keanggotaan dalam organisasi dan bersedia melakukan usaha yang tinggi bagi pencapaian tujuan organisasi.

Hasil penelitian ini konsisten dengan hasil penelitian yang dilakukan oleh Kurniawan, Albert. (2015), yang menyatakan bahwa komitmen organisasional berpengaruh positif signifikan terhadap OCB. Sedangkan hasil penelitian ini berbeda dengan penelitian yang dilakukan Arum Darmawati, dkk. (2013) menyimpulkan komitmen organisasi tidak berpengaruh secara signifikan terhadap Organizational Citizenship Behaviour. c. Pengaruh Leader Member Exchange Terhadap Kinerja Karyawan

Hasil penelitian diperoleh nilai 0,391 dengan nilai $P$-value (signifikan) sebesar 0,032 lebih kecil dari 0,05, sehingga Leader Member Exchange berpengaruh signifikan terhadap Kinerjapada karyawan Kospin Jasa Pekalongan. Menurut Schaufeli, dkk (2002) LMX yang berkualitas dapat meningkatkan keterlibatan kerja bawahan karena bawahan akan lebih semangat, berdedikasi,berenergi, dan merasa waktu berlalu begitu cepat ketika mereka bekerja.

Salah satu yang harus diperhatikan oleh para pemimpin adalah kualitas hubungan antara pemimpin dan karyawan. Teori yang mengatur hubungan antara pemimpin dan karyawan ini disebut Leader Member Exchange atau yang lebih dikenal dengan istilah LMX. Liden dan Maslyn (1998, p.50) menyatakan bahwa perilaku yang berhubungan dengan pekerjaan, menghormati keterampilan para pemimpin dan pengetahuan, kesetiaan kepada satu sama lain, dan menyukai satu sama lain dapat berkontribusi untuk pengembangan LMX. Sistem kepemimpinan Leader Member Exhange dalam penerapannya dapat menghasilkan feedback antar individu tanpa terpengaruh batas atau strata sosial. Pemimpin dan karyawan dapat berkomunikasi tanpa memandang senioritas dan jabatan sehingga dapat berdampak positif terhadap perusahaan, yaitu berupa peningkatan kinerja karyawan.

Keterkaitan antara Leader Member Exchange dengan kinerja ini telah dibuktikan oleh beberapa ahli seperti Wang (2016) yang berpendapat bahwa Leader Member Exchange terkait secara positif dengan kinerja karyawan. Arsintadiani dan Harsono (2002) juga telah membuktikan bahwa Leader Member Exchange berpengaruh secara positif terhadap kinerja karyawan. 
d. Pengaruh Komitmen Organisasional Terhadap Kinerja Karyawan

Hasil penelitian diperolehnilai 1,296 dengan nilai $P$-value (signifikan) sebesar 0,022 lebih kecil dari 0,05, sehingga Komitmen Organisasi berpengaruh signifikan terhadap Kinerja pada karyawan Kospin Jasa Pekalongan.Komitmen organisasi merupakan loyalitas karyawan terhadap organisasi dan proses yang terus menerus dimana karyawan menunjukan dan mengekspresikan perhatian atau hal yang penting terhadap organisasi. Karyawan yang memiliki komitmen organisasi yang tinggi akan memberikan kontribusi yang besar kepada perusahaan karena mereka mau bekerja semaksimal mungkin dan berperilaku baik dalam mencapai tujuan perusahaan, maka komitmen organisasi berpengaruh terhadap kinerja karyawan.

Hasil penelitian ini konsisten dengan hasil penelitian yang dilakukan oleh Penelitian Ghorbanpour, Dehnavi, Heyrani (2014) yaitu komitmen organisasi memiliki pengaruh positif yang signifikan pada kinerja karyawan. Sedangkan penelitian Arizona, Riniwati Harahap (2013) mengatakan Secara parsial komitmen organisasional tidak mempunyai pengaruh yang signifikan terhadap kinerja pegawai.

\section{e. Pengaruh Organizational Citizenship} Behaviour Terhadap Kinerja Karyawan

Hasil penelitian diperoleh nilai 0,775 dengan nilai $P$-value (signifikan) sebesar 0,017 lebih kecil dari 0,05 , sehingga Komitmen Organisasi berpengaruh signifikan terhadap Organizational Citizenship Behaviour pada karyawan Kospin Jasa Pekalongan. Perilaku OCB merupakan salah satu bentuk dari adanya teori pertukaran sosial dimana terdapat rasa saling percaya dan imbal balik di antara kedua belah pihak, yaitu karyawan dan perusahaan
(Widyaningrum, 2010). Apabila individu merasa perlakuan organisasi baik maka mereka akan membalas dan meningkatkan kinerja melebihi permintaan minimum pekerjaannnya dengan membantu yang lain dan organisasi, sebaliknya jika organisasi memandang tenaga kerja dalam jangka pendek maka mereka akan membalas dengan hanya melakukan tugasnya saja dan meminimalisasi perilaku OCB.

Gibson, et al (2011) berpendapat bahwa organizational citizenship Behaviour sangat penting dalam kelangsungan hidup organisasi. Perilaku organisasional bisa memaksimalkan efisiensi dan produktivitas karyawan maupun organisasi yang pada akhirnya memberi kontribusi pada fungsi efektif dari suatu organisasi

Hasil penelitian ini konsisten dengan hasil penelitian yang dilakukan oleh Aini, Nur. (2016), yang menyimpulkan bahwa OCB berpengaruh positif signifikan terhadap kinerja karyawan. Sedangkan hasil penelitian ini berbeda dengan penelitian yang dilakukan Firman, et al. (2015) menyimpulkan Organizational citizen behaviour berpengaruh positif namun tidak signifikan terhadap kinerja karyawan.

\section{KESIMPULAN DAN SARAN}

\subsection{Kesimpulan}

Berdasarkan hasil analisis data dan pembahasan, maka dapat disimpulkan sebagai berikut:

a. Leader member Exchange berpengaruh terhadap organizational citizenship behavior karyawan Kospin Jasa Pekalongan.

b. Komitmen organisasi berpengaruh terhadap organizational citizenship behavior karyawan Kospin Jasa Pekalongan. 
c. Leader member Exchange berpengaruh terhadap kinerja karyawan Kospin Jasa Pekalongan.

d. Komitmen organisasi berpengaruh terhadap kinerja karyawan Kospin Jasa Pekalongan.

e. Organizational Citizenship Behavior berpengaruh terhadap kinerja karyawan Kospin Jasa Pekalongan.

f. Leader member exchange berpengaruh tidak langsung terhadap kinerja karyawan melalui organizational citizenship behavior karyawan Kospin Jasa Pekalongan.

g. Komitmen organisasi berpengaruh tidak langsung terhadap kinerja karyawan melalui organizational citizenship behavior karyawan Kospin Jasa Pekalongan.

\subsection{Saran}

Berdasarkan hasil analisis data dan pembahasan, maka dapat disimpulkan sebagai berikut:

1. Leader member Exchange berpengaruh terhadap organizational citizenship behavior karyawan Kospin Jasa Pekalongan.

2. Komitmen organisasi berpengaruh terhadap organizational citizenship behavior karyawan Kospin Jasa Pekalongan.

3. Leader member Exchange berpengaruh terhadap kinerja karyawan Kospin Jasa Pekalongan.

4. Komitmen organisasi berpengaruh terhadap kinerja karyawan Kospin Jasa Pekalongan.

\section{DAFTAR PUSTAKA}

Adrie Oktavio. 2013. "Pengaruh Leader Member Exchange dan Perceived Organizational Support Terhadap
Organizational Citizenship Behavior

(Studi pada Staf Administrasi Universitas Kristen Petra Surabaya)". Artikel Penelitian. Universitas Pembangunan Nasional "Veteran" Jawa Timur.

Amiruddin Prisetyadi. 2011. "Pengaruh Leader Member Exchange Terhadap Komitmen Organisasi pada PT. Midian Karya Pasuruan". Jurnal Manajemen Bisnis. Volume 1 No. 01. Edisi April 2011.

Arif Hidayat dan Ratna Kusumawati. 2014. "Pengaruh Komitmen Organisasi dan Kepuasan Kerja terhadap Organizational Citizenship Behavior (OCB) di PT. Argamukti Pratama Semarang”. Artikel Penelitian. Universitas Wahid Hasyim Semarang.

Arizona Dika, Riniwati Harsuko, Harahap Nuddin.2013. "Analisis Pengaruh Gaya Kepemimpinan,Motivasi Kerja dan Komitmen Organisasional terhadap Kinerja Pegawai”, Vol. I No. 1 pp 1-11.

Arsintadiani, D. dan M. Harsono. 2002. Pengaruh tingkat LMX terhadap Penilaian Kinerja dan Kepuasan Kerja dengan Kesamaan Gender dan Locus of Control sebagai Variabel Moderator. Jurnal Perspektif. (2): 113-122.

Asgari Ali, Abu Daud Silong, Aminah Ahmad dan Bahaman Abu Samah. 2008. "The relationship between leadermember exchange, organizational inflexibility, perceived organizational support, interactional justice and organizational citizenship behaviour". African Journal of Business Management, Vol.2, No. 8.

Bernardin, H. John, dan Joyce E.A Russel. 2003. Human resource management. (An Experimental Approach International Edition). Mc. Graw-Hill Inc. Singapore. 
Bhal. OC. 2006. Organizational Citizenship

Behavior: the good soldier syndrome. Lexington, MA: Lexington Book.

Dian Kartika dan Suharnomo. 2016. "Pengaruh Pertukaran PemimpinAnggota (LMX) Terhadap Kinerja Karyawan Dengan Kepuasan Kerja Dan Keterlibatan Karyawan Sebagai Variabel Mediasi (Studi Pada Hotel Bahari Inn Tegal)". Diponegoro Journal of Management. Volume 5, Nomor 2, Tahun 2016, Halaman 1-14.

Gibson, dkk. 2011. Organisasi : Perilaku, Struktur, Proses, Edisi Kelima, Jilid 1, Alih Bahasa Djarkasih, Erlangga, Jakarta.

Harris, K.J. 2004. "An Examination on Multiple Predictors and Outcomes from Different Dimensions of LMX Relationship Quality. Unpublished Phd Thesis. College of Business, The Florida State University.

Hueryren Yeh, Dachuan Hong. 2012. "The Mediating Effect of Organizational Commitment on Leadership Type and Job Performance". The Journal of Human Resource and Adult Learning, Vol. 8, Num. 2, Taiwan.

Liden, Robert C., Raymond T. Sparrowe, dan Sandy J.Wayne. 1997. "Leader Member Exchange Theory: The Past and Potential for the Future". Journal Personnel and Human Resources Management. Vol.15.

Luthans, Fred. 2006. Perilaku Organisasi. (Alih Bahasa V.A Yuwono, dkk),Edisi. Bahasa Indonesia, Yogyakarta: ANDI. Mangkunegara, A. 2011. Manajemen Sumber Daya Manusia. Bandung: PT. Remaja Rosdakarya.

Mathis, R., and Jackson, H. 2006. Manajemen Sumber Daya Manusia. D. Jimmy Sadeli, Penerj. Jakarta: Salemba Empat.
Morrow, K Settoon, R. P, Benett, N, \& Liden, R. C. 2005. "Social Exchange in Organizations: Perceived Organizational Support, Leader Member Exchange, and Employee Reciprocity". Journal of psychology, 81.

Truckenbrodt. Yolanda B. 2002. Leader member exchange and commitment and organizational citizenship behavior. Journal of Acquisition Review Quarterly.

Organ, D.W., Podsakoff, P.M., \&MacKanzie S,P,. 2006. Organizational citizenship Behavior: Its nature, incidents, and conseqiences.London: Sage Publications.

Wang, \& Law . 2001. "The Linkage Role of LMX: A Mediating Effect of LMX on the Relationship between Transformational Leadership and Followers' Performance, and OCB". Journal of Management.

Wulandari. 2015. "Pengaruh Kepuasan Kerja dan Komitmen Organisasi Terhadap Organizational Citizenship Behavior Perawat Rumah Sakit Islam Yogyakarta". Arttikel Penelitian. 